\title{
A Study on the Utilization of Dendropanax morbifera Lev. Leaf Extract for Material of Functional Cosmetics and Hair Growth Products
}

Yun Mi Park, Jin Seop Han *

Department of Cosmetology Science, Graduate School of Nambu University, Gwangju, Korea

\author{
"Corresponding author: Jin Seop Han, \\ Department of Cosmetology Science, \\ Graduate School of Nambu University, 23 \\ advanced Jungang-ro, Gwangsan-gu, Gwangju \\ 62271, Korea \\ Tel.: +82629700163 \\ Fax: +82 629700491 \\ Email: jsh52@nambu.ac.kr
}

\section{Received May 16, 2016}

Revised July 14, 2016

Accepted July 22, 2016

Published September 30, 2016

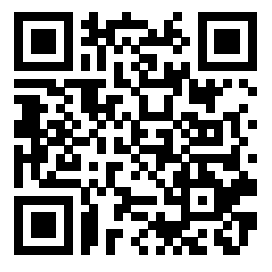

\begin{abstract}
Purpose: This study was conducted to provide data of the material development of functional cosmetics and hair growth products that could replace the drug therapies by extracting the active ingredients from Dendropanax morbifera (D. morbifera) leaf using the methanol-ultrasound extraction method. Methods: Total polyphenol and flavonoid contents of $D$. morbifera leaf methanol-ultrasound extract were measured. Also, the anti-oxidant capacity, nitrite scavenging ability, antimicrobial activity, and the minimum inhibitory concentration (MIC) were measured. Cytotoxicity of the extract on HFDPCs was examined by MTT assay at concentrations of 10,100 , and $500 \mu \mathrm{g} / \mathrm{mL}$, respectively. Moreover, the promotive and inhibitory effects of growth factor expression were also confirmed through the western blotting. Results: Total polyphenol and flavonoid contents of $D$. morbifera leaf methanol-ultrasound extract were $74.082 \pm 7.180 \mathrm{mg} / \mathrm{g}$ and $97.360 \pm 2.235 \mathrm{mg} / \mathrm{g}$, respectively. DPPH scavenging ability was $92.440 \pm 1.023 \%$, which was very high, and the nitrite scavenging activity was $52.6 \pm 2.4 \%$. Antimicrobial activities were investigated in the strains such as Propionibacterium acnes (P. acnes), Pityrosporum ovale (P. ovale), and Malassezia furfur (M. furfur). The MIC of $P$. acnes, $P$. ovale, and $M$. furfur were $17.3 \%, 21.6 \%$, and $15.7 \%$, respectively. Cytotoxicity was not observed within the range of concentrations $(10,100$, and $500 \mu \mathrm{g} / \mathrm{mL})$ of $D$. morbifera leaf methanol-ultrasound extract and the cell growth rate was increased according to the concentrations. In case of the growth factor expression by western blotting, high promotive effect was observed in IGF protein expression (156 $\pm 8 \%$ ) compared with the control group, while inhibitory effect was confirmed in TGFß2 protein expression (78.3 $\pm 10 \%)$. Conclusion: Therefore, it is possible to utilize $D$. morbifera leaf methanolultrasound extract as the material of functional cosmetics and hair growth products with anti-oxidant capacity.
\end{abstract}

Keywords: Dendropanax morbifera, Human hair follicle dermal papilla cell, Western blotting, Growth factor protein, DPPH

\section{Introduction}

최근에는 신체적, 정신적 건강을 위한 자연주의 열풍으로 식품 분야뿐만 아니라 화장품분야에서도 천연물에 대한 관심이 높아 지고 있는 추세이다. 특히 기능성 화장품 시장이 활성화되면서 화 학 성분의 부작용을 최소화 할 수 있는 새로운 기능성 물질을 천연 물로부터 찾으려는 연구와 노력이 활발하게 진행되고 있으며, 천
연물 추출물에 대한 안전성과 효능에 대해 많은 관심을 갖고 있다 (Youm \& Lim, 2010; Kim \& Kim, 2007).

황칠나무(Dendropanax morbifera Léveille)는 두릅나무 과 식물로 우리나라의 황칠나무는 속 1종의 고유수종으로서 남해 안 지역의 도서지방과 제주도의 한라산 일대에 자생하며 수피에 상처를 주면 황색의 수지액이 나오는데 이것을 황칠이라고 한다 (Moon et al, 1999). 두릅나무과는 한국에서 최고의 약재들로 손 
꼽히는 인삼(Panax ginseng), 가시오갈피(Eleutherococcus senticosus) 등의 약용식물을 포함하고 있는 종이다(Bae et al., 2009). 이에 속하는 황칠나무는 겨울에도 낙엽이 지지 않는 난대 상록 교목으로 과거 제주도, 완도, 거문도, 해남, 거제도 등 서 · 남해안 및 도서지역을 포함하는 난· 온대의 넓은 지역에 분포하 였으나 무분별한 남획과 국토의 도시화에 의한 관리소홀로 인하 여 대부분의 자생지가 파괴되어 도서지역 일부에만 국한적으로 생육하고 있다(Lee et al., 2013).

황칠나무에 함유되어 있는 성분으로는 세스퀴테르펜 (sesquiterpene)에 속하는 $\beta$-selinene, capnellane-8-one이 함유되어 있으며, 황칠나무 잎, 줄기, 가지, 껍질에는 페놀, 플 라보노이드 화합물인 chlorogenic acid, caffeic acid, rutin, rosmarinic acid가 있다고 보고되고 있다. 황칠나무는 학명에서 뜻하는 바와 같이 목본(dendro), 전능약(panax) 이라는 의미가 있어 예로부터 모든 병을 치료하는 만병통치나무라고 불려왔다 (Choi, 2003). 황칠나무는 항암, 항산화, 미백, 당뇨 치료, 간세포 재생, 신경조직세포 재생효과가 있을 뿐만 아니라, 독특한 방향성 분인 안식향산(벤조산, benzoic acid) (Lee et al., 2013)을 함유하 여 신경계에 대한 진정작용과 강장작용을 나타내 신약 및 기능성 소재로서의 개발 가능성을 높여주고 있다.

소득증대에 따른 생활수준의 향상과 삶의 질에 대한 욕구증가 는 외모와 라이프스타일의 향상을 통한 웰빙(well-being)문화의 확산을 가져오게 하였다. 또한 외모가 개인간의 우열과 성패를 좌 우한다고 믿는 루키즘(lookism)현상 역시 사회적 트렌드로 대두 되면서 건강과 미용에 대한 관심이 증가하였으며, 특히 신체의 모 발은 외모와 건강미를 판단하는 데 그 비중이 상당히 크다고 할 수 있다(Kim \& Han, 2014).

현대사회에서 나타나는 탈모는 노화현상과 유전적 요인에 의해 발생한다는 기존의 개념과는 달리 스트레스, 서구화된 식습관으로 인한 영양 불균형 등 사회 · 문화적인 요인들의 변화에 의해 발생 하며, 탈모로 고통 받고 있는 인구가 늘어나고 있어 최근에는 20 대 여성은 물론 젊은 학생들까지 탈모를 걱정하는 시대가 됨에 따라 탈모예방을 위한 다양한 정보와 탈모치료 관련시장이 증가하고 있 다(Lee \& Hwang, 2009). 최근에는 모발성장과 관련하여 한약재 와 생약추출물 등 천연물을 이용한 치료제 및 치료법에 대하여 많 은 연구가 진행되고 있으며 전통적으로 한방에서는 많은 식물추출 물들이 탈모예방 및 발모에 사용되어 왔으며 안전성에 있어서 우 수한 것으로 알려져 왔다(Hyung et al, 2007).

인간모유두세포(human hair follicle dermal papilla cell, $\mathrm{HFDPC}$ )는 발생학적으로 간엽계에서 유래된 세포로 주위의 상피계 세포의 분열을 조절하는 능력이 있으며, 이러한 기능 은 성장인자에 의해 조절된다고 알려져 있다(Randall et al., 2001). 현재까지 모낭에서 발현되는 것으로 보고된 성장인자로 는 insulin like growth factor 1 (IGF1), vascular endothelial growth factor (VEGF), hepatocyte growth factor (HGF), keratinocyte growth factor (KGF), fibroblast growth factor 1 (FGF1) 등이 있다(Philpott et al., 1994). 최근에는 성장인자 중 하나인 VEGF를 이용하여 모낭 주위에 새로운 혈관을 형성, 혈액순환 을 촉진시킴으로써 탈모를 개선한다는 보고도 있다(Kwonet al, 2007).

Transforming growth factor beta 2 (TGFß2)는 모발이 성 장기에서 퇴행기로 이행될 때 모낭에서 발현되는 것이 알려지면 서 퇴행기를 유도하는 핵심인자로 알려져 있으며(Foitzik et al., 2005; Jamora et al., 2005), 상피세포의 증식을 억제하고, 퇴행 기로의 이행을 촉진시켜 인간의 모주기를 짧게 하는 것으로 알려 져 있다(Hibino \& Nishiyama, 2004). Dickkopf WNT signaling pathway inhibitor 1 (DKK1)은 DKK1 유전자에 의해 합성되는 단 백질로 모낭의 길이를 감소시키고 모낭의 퇴화를 촉진시키며, keratinocyte의 활성을 조절함으로써 성장기에서 퇴행기로의 모주 기 이행에 관여한다. 성장기의 모발에 DKK1을 처리할 경우 퇴행 기로 조기 이행되는 것이 관찰되어 탈모에 영향을 미치는 것으로 알려져 있다(Kwack et al., 2012).

본 연구에서는 실험적 방법을 통하여 부작용이 없는 안전한 천 연물로 알려진 황칠나무 잎에서 메탄올-초음파 추출법으로 유효 성분을 추출한 후, 항산화 활성평가와 피부질환을 유발하는 것 으로 보고된 균 중 여드름 유발균(Propionibacterium acnes, P. acnes), 모낭염 유발균(Pityrosporum ovale, P. ovale), 지 루성피부염 유발균(Malassezia furfur, M. furfur) 3 종의 균 주에 대하여 항균효과를 측정하였다. 또한, $\mathrm{HFDPC}$ 에 대하여 3-(4,5-Dimethylthiazol-2-yl)-2,5-diphenyltetrazolium bromide (MTT)assay로 세포독성 및 세포증식효과가 있는지 를 알아 보았으며, western blotting을 통한 성장인자인 VEGF, IGF, HGF와 퇴행기를 유도하는 인자인 TGFß2, DKK1의 발현 에 미치는 영향을 확인하여 약물요법을 대체할 수 있는 천연성 분을 이용한 육모제 및 기능성 화장품 소재활용 가능성과 그 과 학적 근거를 제시하고자 본 연구를 진행하였다.

\section{Methods}

\section{1. 실험재료 및 시약}

1) 생약제제 및 시약

본 연구에 사용한 황칠나무 잎은 전남 화순에 소재한 전남생 약농업협동조합(Korea)에서 건조된 상태로 구입 사용하였다. 추 출에 사용된 유기용매는 일급시약을 구입하여 사용하였다. 항산화 효능분석에 사용된 시약인 2,2-diphenyl-1-picrylhydrazyl (DPPH), L-ascorbic acid, tannic acid, naringin, sodium nitrite, diethylene glycol, griess reagent는 Sigma-Aldrich (USA)에서 구입하여 사용하였다. 


\section{2) 세포 및 모발성장인자}

본 연구에서 사용한 인간모유두세포 $(\mathrm{HFDPC})$ 와 전용배지 (Follicle Dermal Papilla Cell Growth Medium)는 PromoCell $\mathrm{GmbH}$ (Germany)에서 구입하여 사용하였다. 모발성장인자인 KGF, IGF1, VEGF의 1차 항체는 PeproTech (USA)에서 구입 하였고, TGFB2와 DKK1의 1차 항체와 2차 항체인 goat antirabbit IgG-HRP는 Santa Cruz Biotechnology Inc. (USA) 에서 구입하였다.

\section{2. 실험방법}

\section{1) 메탄올-초음파 추출}

황칠나무 잎의 메탄올-초음파 추출을 위해 Kwon et al. (2008) 의 방법을 수정하여 사용하였다. 잘게 분쇄한 황칠나무 잎 $20 \mathrm{~g}$ 에 $70 \%$ 메탄올(methanol)을 가하여 총량이 $0.5 \mathrm{~L}$ 가 되도록 준비 하고, 초음파분산기(VC750; Sonics, USA)를 사용하여 $30 \mathrm{~min}$ 동 안 $60 \mathrm{kHz}$ 의 초음파를 발생시킨 후 $72 \mathrm{~h}$ 동안 암 상태로 실온에 보관하여 추출하였다. 시료 추출물은 5 장을 겹친 거즈로 1 차 여 과한 후 2차로 추출용 여과지(Whatman filter paper No. 2; GE healthcare, UK)에 통과 시킨 후 추출물을 Eyela rotary vacuum evaporator (N-1000; Tokyo Rikakikai Co., Ltd., Japan)로 감압 증류하여 용매를 완전하게 휘발시킨 후 동결 건조하였다. 동 결 건조된 분말시료는 사용 전까지 $-20^{\circ} \mathrm{C}$ 에서 냉동 보관하였다.

\section{2) 총 폴리페놀 함량 측정}

총 폴리페놀 함량은 Folin \& Denis (1912) 방법을 수정하여 측 정하였다. 메탄올로 용해하여 $1 \mathrm{mg} / \mathrm{mL}$ 농도로 준비한 시료 100 $\mu \mathrm{L}$ 에 Folin-Denis reagent (Fluka, Switzerland)를 $100 \mu \mathrm{L}$ 을 가하여 혼합한 후 $3 \mathrm{~min}$ 동안 실온에 반응시켰다. $3 \mathrm{~min}$ 후 $10 \%$ sodium carbonate solution $100 \mu \mathrm{L}$ 을 가하여 혼합하고 $1 \mathrm{~h}$ 반응시 킨 후 상층액을 취하여 microplate reader (Molecular Devices, $\mathrm{USA}$ )를 이용하여 $760 \mathrm{~nm}$ 에서 흡광도를 측정하였다. 총 폴리페놀 함량은 tannic acid의 표준검량곡선을 이용하여 측정하였다.

\section{3) 총 플라보노이드 함량 측정}

총 플라보노이드 함량 측정은 Kim et al. (2012)의 방법으로 측 정하였으며, 메탄올로 용해하여 $1 \mathrm{mg} / \mathrm{mL}$ 농도로 준비한 시료 $100 \mu \mathrm{L}$ 에 diethylene glycol을 $1 \mathrm{~mL}$ 씩 가하여 혼합하였다. 혼합 후 $1 \mathrm{~N} \mathrm{NaOH}$ 를 $100 \mu \mathrm{L}$ 가하여 잘 혼합하고 $37^{\circ} \mathrm{C}$ water bath에 서 $1 \mathrm{~h}$ 동안 반응시켰다. $1 \mathrm{~h}$ 후 microplate reader를 이용하여 $420 \mathrm{~nm}$ 에서 흡광도를 측정하였다. 표준물질로 naringin을 사용 하여 표준검량곡선을 작성하여 측정하였다.

\section{4) $\mathrm{DPPH}$ radical 소거능 측정}

$\mathrm{DPPH}$ radical 소거능은 Kim et al. (2012)의 방법으로 측정하
였으며, 시료는 메탄올을 이용하여 $1 \mathrm{mg} / \mathrm{mL}$ 농도로 준비하였다. $\mathrm{DPPH}$ 시약은 빛을 차단한 상태에서 $0.1 \mathrm{mM}$ 농도가 되도록 메탄 올에 녹여 준비하였다. 시료 $100 \mu \mathrm{L}$ 과 $\mathrm{DPPH}$ 시약 $0.5 \mathrm{~mL}$ 을 넣 고 $20 \mathrm{~min}$ 동안 빛을 차단한 조건에서 반응시킨 후 microplate reader를 이용하여 $517 \mathrm{~nm}$ 에서 흡광도를 측정하였다. 음성 대조 군으로 시료 대신 메탄올을 사용하였고, 양성 대조군으로 시료 대 신 L-ascorbic acid $(1 \mathrm{mg} / \mathrm{mL})$ 를 가하여 동일한 조건으로 실험을 수행하였다. DPPH radical 소거능은 다음과 같은 식을 이용하여 산출하였다.

DPPH radical scavenging activity (\%)

$=[1-($ 시료 처리군의 흡광도/시료 무처리군의 흡광도 $)] \times 100$

\section{5) 아질산염 소거능 측정}

아질산염 소거능은 Gray \& Dugan (1975)의 방법으로 측정하 였다. $1 \mathrm{mM} \mathrm{NaNO}$ 용액 $50 \mu \mathrm{L}$ 에 $1 \mathrm{mg} / \mathrm{mL}$ 농도의 시료 $50 \mu \mathrm{L}$ 를 첨가하고, 여기에 $0.1 \mathrm{~N} \mathrm{HCl}$ 용액(pH 1.2)을 $300 \mu \mathrm{L}$ 가하여 반 응용액의 최종부피를 $0.4 \mathrm{~mL}$ 로 하여 $37^{\circ} \mathrm{C}$ 에서 $1 \mathrm{~h}$ 반응시켰다. 반응 후 $2 \%$ acetic acid 용액 $2 \mathrm{~mL}$, griess reagent $0.2 \mathrm{~mL}$ 를 가하여 잘 혼합한 다음, 실온에서 $15 \mathrm{~min}$ 동안 반응시키고 microplate reader를 이용하여 $520 \mathrm{~nm}$ 에서 흡광도를 측정하여 잔존하는 아질산염의 양을 산출하였다. 대조군으로 시료 대신 증 류수를 사용하였고, 음성 대조군으로 griess reagent 대신 증류수 를 사용하였고, 양성 대조군으로는 시료 대신 L-ascorbic acid (1 $\mathrm{mg} / \mathrm{mL}$ )를 가하여 동일한 조건으로 실험을 수행하였다. 아질산 염 소거능은 다음과 같은 식을 이용하여 억제율을 산출하였다.

$$
\begin{aligned}
& \text { Nitrite scavenging activity }(\%) \\
& =[1-(\text { 시료 처리군의 흡광도/시료 무처리군의 흡광도 })] \times 100
\end{aligned}
$$

\section{6) Paper disc 방법을 이용한 항균활성 측정}

본 연구에서는 한천배지를 이용한 paper disc 방법을 이용하여 항균력을 확인하였다(Bauer et al., 1966; Piddock, 1990). 순수 분리된 각 균주의 단일집락을 취해 $10 \mathrm{~mL}$ 의 균생육 액체배지에 접 종하여 각 균주를 $37^{\circ} \mathrm{C}$ 에서 $18-24 \mathrm{~h}$ 동안 배양 및 활성화시키고, 3 회 계대배양한 후 항균효과 시험균주로 사용하였다. 항균성 시험 용 평판배지의 조제는 $15 \%$ 의 한천이 첨가된 각 균주의 생육배지를 멸균하여 petridish에 $15 \mathrm{~mL}$ 씩 분주하여 기층용 배지를 응고시키 고, 균 농도를 $0.4 \times 10^{6} \mathrm{CFU} / \mathrm{mL}$ 가 되게 한 후 $0.7 \%$ 한천이 첨가 된 중층용 배지를 $5 \mathrm{~mL}$ 씩 시험관에 분주하여 멸균한 후, 각종 시 험균액 $0.1 \mathrm{~mL}$ 를 무균적으로 가하여 잘 혼합한 다음 기층용 배지 위에 분주한 다음 고르게 응고시켜 2 중의 균접종 중층배지를 만들 어 실험에 사용하였다. 충분히 굳은 중층 배지위에 멸균된 paper $\operatorname{disc}(8 \mathrm{~mm})$ 를 올려 놓은 후 $0.5-5 \mathrm{mg} / \mathrm{disc}$ 가 되도록 추출물을 
dimethyl sulfoxide (DMSO; Amresco, USA)에 희석하여 흡수 시켰다. 각 균주는 $37^{\circ} \mathrm{C}, 24 \mathrm{~h}$ 배양시킨 후 paper disc 주변에 형 성된 clear zone의 직경을 측정하여 항균효과를 비교하였다.

\section{7) 최소성장저해농도 $(\mathrm{MIC})$ 측정}

항균효과 실험으로 최소성장저해농도(minimum inhibitory concentration, MIC) 측정은 broth microdilution method (Reuben et al., 1989)를 이용하였다. 고체배지에서 자란 각 균 주의 단일 집락을 $10 \mathrm{~mL}$ 의 액체배지에 접종하여 각 균의 최적 생육온도에서 $12 \mathrm{~h}$ 동안 액체배지에서 2회 계대배양하였다. 96 well microplate에 배지를 각각 $100 \mu \mathrm{L}$ 씩 분주하고 시료를 100 $\mu \mathrm{L}$ 씩 2 배 희석하여 농도를 조절한 후 각각의 시험균은 대수증 식기 중기(2-6 h 배양 후)에 도달하였을 때 배양액을 균의 농 도가 $2 \times 10^{4}-10^{5} \mathrm{CFU} / \mathrm{mL}$ 이 되도록 희석시켜 well당 $100 \mu \mathrm{L}$ 씩 첨가하였다. 그 후 $37^{\circ} \mathrm{C}$ 에서 $24 \mathrm{~h}$ 배양한 뒤, $650 \mathrm{~nm}$ 에서 microplate reader로 흡광도를 측정하였다.

\section{8) 모유두세포(HFDPC)에 대한 세포독성 및 세포증식효과}

메탄올-초음파 추출물이 모유두세포( $\mathrm{HFDPC})$ 의 생존율에 미치는 영향은 Mosmann (1983)의 방법을 통해 확인하였다. $\mathrm{HFDPC}$ 는 $37^{\circ} \mathrm{C}, 5 \% \mathrm{CO}_{2}$ 조건에서 세포 배양정도(confluency) 가 80-85\% 될 때까지 전배양을 하였다. 전배양 세포가 적정수준 까지 자라면 세포를 분리하여, 24 well plate에 초기 confluency 가 20-25\% 되도록 세포를 접종한 후 confluency가 70-80\% 되게 추가 배양하였다. 배양액을 흡인제거하고 $37^{\circ} \mathrm{C}$ 로 데워진 Follicle Dermal Papilla Cell Growth Medium $1.0 \mathrm{~mL}$ 씩 배지를 교환하 였다. 황칠나무 잎 메탄올-초음파 추출물을 대조군과 함께 처리 하였으며, 대조군으로는 샘플을 용해하는데 사용된 phosphate buffered saline (PBS)을 동량으로 처리하였다. 추출물은 최종농 도가 $10,100,500 \mu \mathrm{g} / \mathrm{mL}$ 이 되도록 처리한 후 $48 \mathrm{~h}$ 추가 배양하 였다. 배양 완료 후 $100 \mu \mathrm{L}$ 의 MTT solution을 각 well에 첨가하 고 잘 섞어 $3 \mathrm{~h}$ 동안 세포배양기에서 배양하여 MTT가 환원되도 록 하였다. 배양액을 흡인하여 완전히 제거한 후 각 well에 생성 된 formazan 결정을 DMSO $200 \mu \mathrm{L}$ 를 가하여 녹인 다음 96 well plate로 $100 \mu \mathrm{L}$ 씩 옮겨 microplate reader를 이용하여 $550 \mathrm{~nm}$ 에 서 흡광도를 측정하였다.

\section{9) Western blotting을 통한 모발성장인자 단백질 발현 측정}

황칠나무 잎 메탄올-초음파 추출물이 인간모유두세포 ( $\mathrm{HFDPC}$ )의 $\mathrm{IGF}, \mathrm{VEGF}, \mathrm{HGF}, \mathrm{TGF} \beta 2, \mathrm{DKK} 1$ 단백질 발현에 미치는 영향을 확인하기 위해 western blotting 방법을 이용하 였다. 추출물을 $100 \mu \mathrm{g} / \mathrm{mL}$ 의 농도로 $48 \mathrm{~h}$ 동안 처리한 후 상 층액을 제거하고, $\mathrm{PBS}$ 로 2회 세척한 뒤 $150 \mathrm{mM} \mathrm{NaCl}, 5 \mathrm{mM}$ ethylenediaminetetraacetic acid (EDTA, pH 8), 50 mM
Tris $-\mathrm{HCl}$ (pH 7.4)를 넣고 sonication을 실시하고 $4^{\circ} \mathrm{C}$ 에서 60 $\min$ 동안 정치시킨 후 $15,000 \times \mathrm{g}, 20 \mathrm{~min}$ 원심분리하여 protein 을 얻었다. 획득한 protein은 bovine serum albumin (BSA)을 표준물질로 하여 Bradford assay로 정량하였고, $20 \mu \mathrm{g}$ protein 을 SDS-polyacrylamide gel에 $100 \mathrm{~V}, 1.5 \mathrm{~h}$ 로 전기영동하 고 electroblotter (HEP-1; McQueen, USA)를 사용하여 70 $\mathrm{V}, 30 \mathrm{~min}$ 동안 PVDF membrane에 옮기고 5\% skim milk solution에 membrane을 담그고 $8 \mathrm{~h}$ 동안 배양하였다. 정상대 조군(normal control, $\mathrm{NC}$ )으로 시료 대신 $\mathrm{PBS}$ 를 동일량 첨가 하여 사용하였으며, 이후 PBS로 $10 \mathrm{~min}$ 간격, 3회 washing 후 1 차 항체 $(1: 2,500)$ 를 이용하여 $1.5 \mathrm{~h}$ 동안 반응시켰으며, 다시 3 회 세척한 후 2 차 항체( $1: 2,500)$ 로 $1 \mathrm{~h}$ 동안 반응시키고, 3 회 세 척한 후 ECL kit (Amersham Pharmacia Biotech, UK)를 이 용하여 필름에 감광시키는 방법을 이용하여 단백질의 발현을 조 사하였다.

\section{3. 통계처리}

모든 시료의 분석은 3 회 반복 수행되었고, 실험결과는 SPSS package program (Ver. 21; SPSS Inc., USA)을 사용하여 mean \pm S.D. 로 표시하였고, 통계분석은 Student's t-test로 분석하였으며 $p<.05$ 값을 유의성 있는 것으로 해석하였다.

\section{Results and Discussion}

\section{1. 총 폴리페놀 및 플라보노이드 함량}

황칠나무 잎 메탄올-초음파 추출물의 총 폴리페놀 함량과 총 플라보노이드 함량을 분석한 결과 총 폴리페놀 함량은 74.082 $\pm 7.180 \mathrm{mg} / \mathrm{g}$ 로 나타났으며, 총 플라보노이드 함량은 97.360 $\pm 2.235 \mathrm{mg} / \mathrm{g}$ 로 나타났다(Table 1). 이는 Mo \& Oh (2013)의 연 구에서 황칠나무 잎 메탄올 추출물의 총 플라보노이드 함량이 $98.53 \mathrm{mg} / \mathrm{g}$ 로 나타났다는 보고와 일치하는 것이다.

\section{DPPH radical 소거능}

생활환경은 좋아지는 반면에 환경오염 및 현대인들의 과도 한 스트레스, 무분별한 기능성 화장품의 남용 등으로 인하여 피부노화 및 질환이 증가하고 있는 추세이다. 천연 식물체에

Table 1. Total polyphenol and total flavonoid contents of D. morbifera leaf methanol-ultrasound extract

\begin{tabular}{ccc}
$\begin{array}{c}\text { D. morbifera } \\
\text { leaf extract }\end{array}$ & $\begin{array}{c}\text { Total polyphenol contents } \\
(\mathrm{mg} / \mathrm{g})\end{array}$ & $\begin{array}{c}\text { Total flavonoid } \\
\text { contents }(\mathrm{mg} / \mathrm{g})\end{array}$ \\
Methanol-ultrasound & $74.082 \pm 7.180$ & $97.360 \pm 2.235$ \\
\hline
\end{tabular}

Values represent the mean \pm S.D. $(n=3)$ 


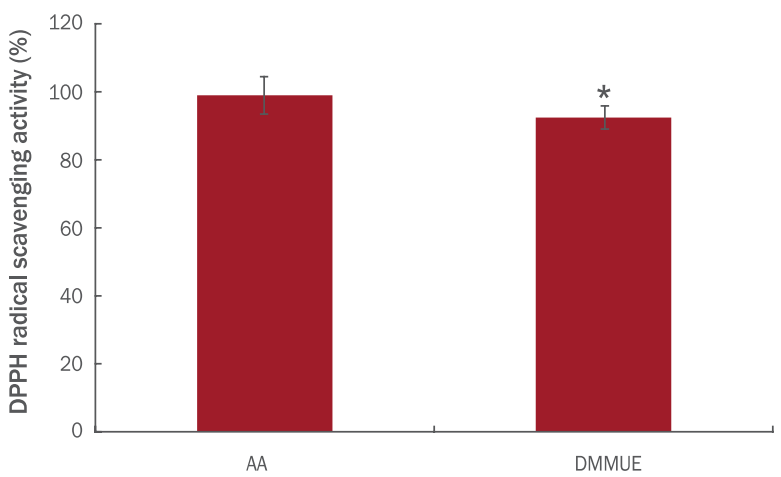

Figure 1. Anti-oxidant effect of $D$. morbifera leaf methanolultrasound extract.

The anti-oxidant effect of $D$. morbifera leaf methanolultrasound extract (DMMUE) was confirmed by DPPH radical scavenging assay. The value of the DMMUE $(1 \mathrm{mg} / \mathrm{mL})$ was similar to the value of L-ascorbic acid (AA, $1 \mathrm{mg} / \mathrm{mL}$ ) used as positive control. Values represent the mean \pm S.D. of triplicates determinations. The Student's t-test was performed to determine statistical significance $\left({ }^{*} p<.05\right.$ compared with control).

주로 존재하는 폴리페놀과 같은 항산화 물질은 생체 내 활성 산소의 반응성을 감소시켜 피부질환을 예방하고 지연시키는 효과가 있어 화장품분야에서 천연 항산화 물질에 대한 많은 연구가 진행되고 있다(Choi et al., 2012; Kim et al., 2001).

황칠나무 잎 메탄올-초음파 추출물의 천연 항산화제로서 의 이용 가능성을 확인하기 위해 항산화 효능분석을 실시하 였다. 추출물과 양성 대조군(L-ascorbic acid)을 각각 $1 \mathrm{mg} /$ $\mathrm{mL}$ 처리하여 DPPH radical 소거능을 분석한 결과 $92.440 \pm$ $1.023 \%, 98.960 \pm 2.758 \%$ 로 나타났다(Figure 1). 황칠나무 잎 메탄올-초음파 추출물이 천연 항산화제인 $\mathrm{L}$-ascorbic acid와 비슷한 활성을 나타내고 있어 천연 항산화제로의 이 용가치가 있다고 사료된다.

\section{3. 아질산염 소거능}

아질산염 소거능 분석은 양성 대조군으로 $1 \mathrm{mg} / \mathrm{mL}$ 농도 의 L-ascorbic acid를 사용하였으며, L-ascorbic acid의 아질산염 소거능은 $96.3 \pm 5.6 \%$ 로 나타났다. 황칠나무 잎

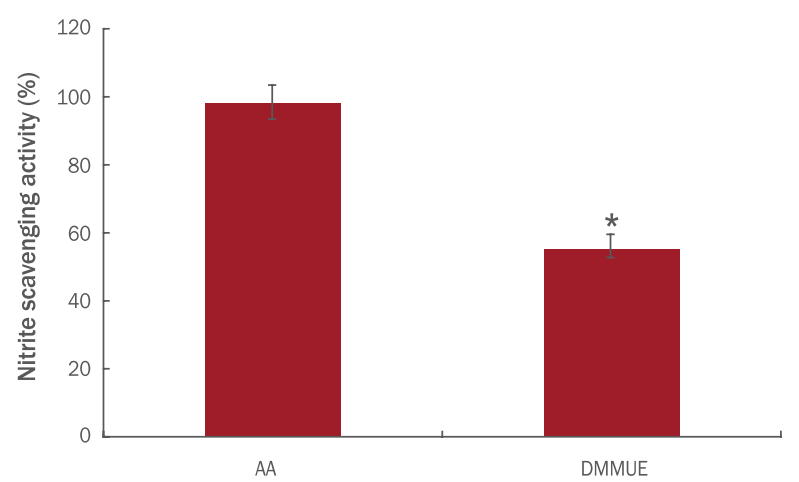

Figure 2. The nitrite scavenging activity of $D$. morbifera leaf methanol-ultrasound extract.

The nitrite scavenging activity of $D$. morbifera leaf methanolultrasound extract (DMMUE, $1 \mathrm{mg} / \mathrm{mL}$ ) was lower than the activity of L-ascorbic acid (AA, $1 \mathrm{mg} / \mathrm{mL}$ ). The values of AA and DMMUE were $96.3 \%$ and $52.6 \%$, respectively. Values represent the mean \pm S.D. of triplicates determinations. The Student's t-test was performed to determine statistical significance $\left({ }^{*} p<.05\right.$ compared with control).

메탄올-초음파 추출물의 아질산염 소거능을 분석한 결과는 $52.6 \pm 2.4 \%$ 로 나타났다(Figure 2).

아질산염은 amine류와 반응하여 nitrosamine을 생 성하는 것으로 알려져 있으며, nitrosamine은 체내에서 diazoalkane $\left(\mathrm{C}_{\mathrm{n}} \mathrm{H}_{2 \mathrm{n}} \mathrm{N}_{2}\right)$ 으로 변화하여 핵산이나 단백질 또 는 세포내의 성분을 alkyl화 함으로써 암을 유발하고, 그 자 신이 독성을 가지고 있다고 하였으며(Bartsch et al,, 1988), Mirvish (1970)는 ascorbic acid에 의한 nitrosamine 생성 억제 기능을 보고하였다. Park et al. (2002)은 쑥과 솔잎 열 수 추출물의 $100 \mathrm{ppm}$ 농도에서 아질산염 소거작용은 쑥은 $10 \%$ 미만, 솔잎은 $11 \%$ 로 나타났다고 보고하였으며, Han et al. (2011)은 민들레의 꽃, 잎, 뿌리, 전체추출물 $1 \mathrm{mg} / \mathrm{mL}$ 에 서 각각 $47.3 \%, 47.1 \%, 41.5 \%, 30.0 \%$ 의 소거활성을 나타냈 다고 보고하였다. 본 연구결과 황칠나무 잎 메탄올-초음파 추출물의 아질산염 소거능은 쑥과 솔잎, 민들레보다 높게 나 타나 아질산염 소거능이 높다는 것을 알 수 있었다.

Table 2. Comparison of the anti-microbial activity of $D$. morbifera leaf methanol-ultrasound extract

\begin{tabular}{cccc}
\hline Concentration(\%) & \multicolumn{3}{c}{${\text { Diameter of inhibition zone }(\mathrm{mm})^{*}}^{*}$} \\
\cline { 2 - 4 } & 0.5 & 1 & 20.9 \\
P. acnes & 11.2 & 15.9 & 16.5 \\
P. ovale & 10.5 & 13.7 & 19.4 \\
\hline
\end{tabular}

*Diameter of clear zone including disc diameter of $8.0 \mathrm{~mm}$ 


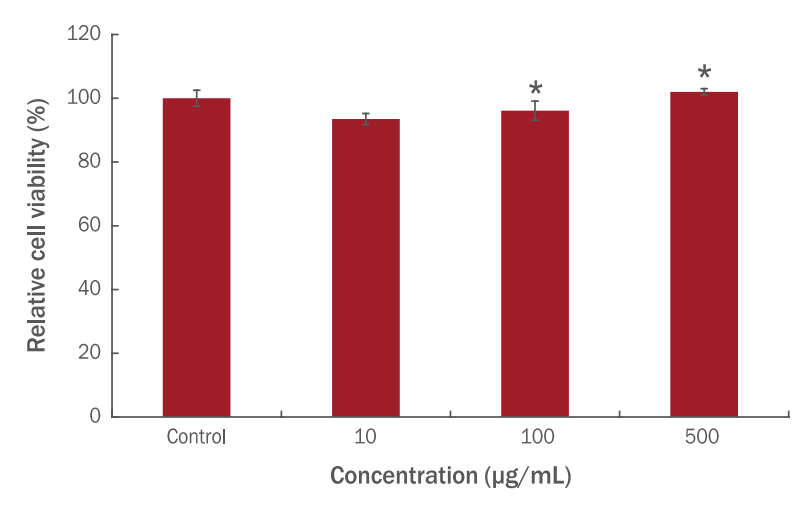

Figure 3. Cytotoxicity of $D$. morbifera leaf methanol-ultrasound extract on HFDPCs.

Confluent cells (70-80\%) were incubated with the extract and cell viability was measured by MTT assay. There is no cytotoxicity at concentrations of $10,100,500 \mu \mathrm{g} /$ $\mathrm{mL}$ of DMMUE extract. Values represent the mean \pm S.D. of triplicates determinations. The Student's t-test was performed to determine statistical significance $\left({ }^{*} p<.05\right.$ compared with control).

\section{Paper disc 방법을 이용한 항균활성 측정}

P. acnes, P. ovale, M. furfur에 대해 paper disc 방법 을 이용하여 황칠나무 잎 메탄올-초음파 추출물의 항균활성 을 확인하였다. 추출물은 $\mathrm{DMSO}$ 에 $0.5 \%, 1 \%, 5 \%$ 로 희석하 여 처리하였으며, 세가지 균주에서 모두 항균활성이 나타났 다. 특히 P. acnes와 M. furfur에서 항균활성이 우수하였다 (Table 2).

\section{5. 최소성장저해농도(MIC) 측정}

황칠나무 잎 메탄올-초음파 추출물에 대하여 최소저해농 도를 측정한 결과를 Table 3 에 나타내었다. P. acnes에서는 $17.3 \%, P$. ovale에서는 $21.6 \%, M$. furfur 에서는 $15.7 \%$ 농도에 서 생육이 저해되었으며, 특히 M. furfur와 P. acnes에서 항 균활성이 우수하였다.

\section{6. 세포독성평가 및 세포증식효과}

황칠나무 잎 메탄올-초음파 추출물을 인간모유두세포에 $10,100,500 \mu \mathrm{g} / \mathrm{mL}$ 의 농도별로 처리하여 MTT assay로 세 포독성을 확인한 결과, 처리농도 범위 내에서 유의적인 세포독 성은 관찰되지 않았다. $\mathrm{PBS}$ 를 처리한 대조군 대비, $10 \mu \mathrm{g} / \mathrm{mL}$ 처리는 $93.5 \pm 3 \%, 100 \mu \mathrm{g} / \mathrm{mL}$ 처리는 $96.1 \pm 5 \%$, 그리고 $500 \mu$ $\mathrm{g} / \mathrm{mL}$ 처리는 $102.0 \pm 2.6 \%$ 의 세포생육도를 보였다(Figure 3 ).

\section{7. 모발성장인자 단백질발현 촉진 및 억제효과}

인간모유두세포에 황칠나무 잎 메탄올-초음파 추출물 100 $\mu \mathrm{g} / \mathrm{mL}$ 의 농도로 $48 \mathrm{~h}$ 처리한 후 모발성장인자 단백질의 발현
A
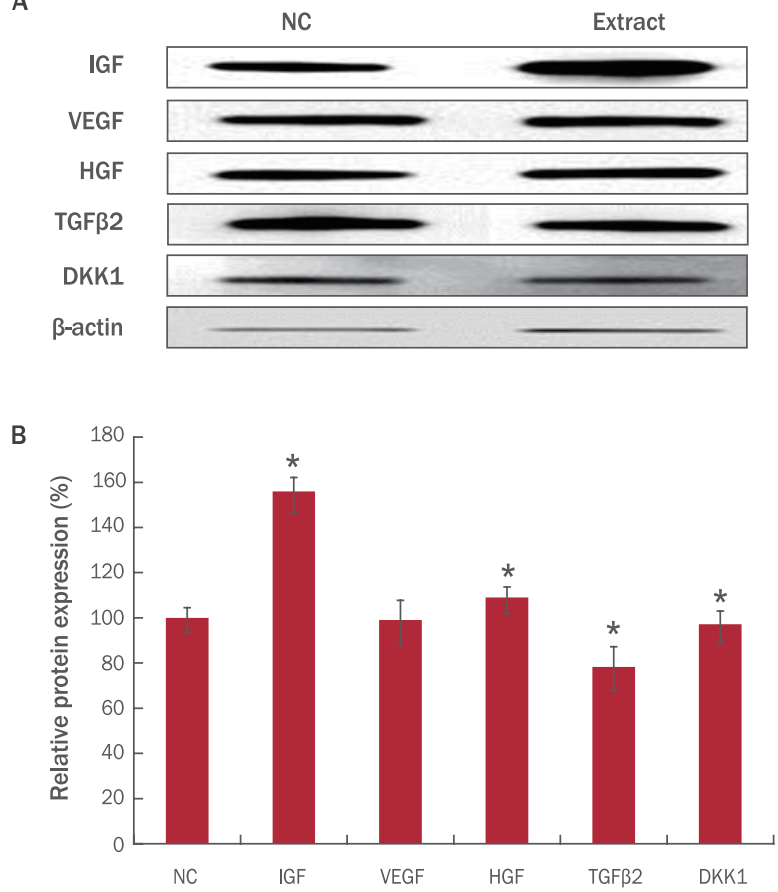

Figure 4. Effects of $D$. morbifera leaf methanol-ultrasound extract on protein expression.

Expressions of growth factors (IGF, VEGF, HGF, TGFB2, and DKK1) were analyzed by western blotting $(A)$ and its relative statistic results were presented with bar graph (B). In the relative protein expression results, value of IGF compared with the value of negative control (NC) was significantly increased (156\%), and VEGF, HGF, TGFß2, and DKK1 were $99 \%, 109 \%, 78.3 \%$, and $97.2 \%$, respectively. Values represent the mean \pm S.D. of triplicates determinations. The Student's t-test was performed to determine statistical significance $\left({ }^{*} p<.05\right.$ compared with NC).

정도에 미치는 영향을 western blotting으로 실험하였다. 대 조군 대비 IGF는 $156 \pm 8 \%$ 로 유의적인 발현촉진효과가 나타났

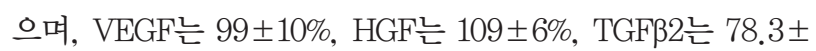
$10 \%, \mathrm{DKK} 1$ 는 $97.2 \pm 7 \%$ 로 나타났다(Figure 4).

성장인자의 모발성장에 미치는 영향에 관해서는 표피성장 인자(EGF), 인슐린유사성장인자(IGF), 섬유아세포성장인자 (FGF), 혈관내피성장인자(VEGF) 등의 성장인자들은 여러 실 험을 통하여 모낭의 특정장소에 작용하여 모발성장에 관여한

Table 3. Minimum inhibitory concentration (MIC) of D. morbifera leaf methanol-ultrasound extract against microorganisms

\begin{tabular}{cc}
\hline Bacteria & MIC (\%) \\
\hline P. acnes & 17.3 \\
P. ovale & 21.6 \\
M. furfur & 15.7 \\
\hline
\end{tabular}


다고 이미 밝혀진 바 있다(Tsuboi, 1997). 1994년에는 Hervert 연구팀에서 섬유아세포 성장인자인 FGF5 유전자가 결핍된 쥐가 비정상적으로 성장기가 길어져 모발이 상대적으로 길어 지며, FGF7, IGF1, HGF는 모발성장을 촉진시키는 주변분비 성장인자(paracrine growth factor)라고 보고하였으며(Lin et al., 2015), 발모 및 탈모에 영향을 미치는 내분비계인자 중 $\mathrm{TGF} 32$ 는 모발의 성장기 단계(anagen stage)의 성장을 방해 하여 정상보다 빨리 퇴행기 단계(catagen stage)로 접어들게 하는 핵심인자로 알려져 있으며(Foitzik et al., 2005; Jamora et al., 2005), 상피세포의 증식을 억제하고, 퇴행기로의 이행 을 촉진시켜 모주기를 짧게 하여 탈모를 유도한다(Hibino \& Nishiyama, 2004)고 알려져 있다. DKK1은 모낭의 길이를 감소시킴으로써 모낭의 퇴화를 촉진시켜 성장기에서 퇴행기 로의 모주기 이행에 관여한다고 알려져 있으며, Kwack et al. (2012)은 성장기 모발에 DKK1을 처리한 결과 조기에 퇴행 기로 이행되는 것이 관찰되었다고 보고하였다. 또한, IGF1, $\mathrm{TGF} \beta 1, \mathrm{EGF}, \mathrm{FGF}$ 등의 성장인자는 모발의 성장을 촉진하 고 모발세포의 퇴화를 방지하여 탈모를 방지한다고 하였다. 본 연구에서는 황칠나무 잎 메탄올-초음파 추출물의 IGF 와 $\mathrm{HGF}$ 성장인자 발현촉진효과는 대조군 대비 각각 $156 \pm$ $8 \%, 109 \pm 6 \%$ ( $p$ 〈.05)로 성장을 촉진시키는 효과를 보였으며, TGFB2는 78.3 $\pm 10 \%$ ( $p$ 〈.05)로 나타나 억제효과를 보였다.

\section{Conclusion}

본 연구는 황칠나무 잎 메탄올-초음파 추출물의 항산화능 과 항균활성을 측정하고 인간모유두세포에 대한 세포독성 및 세포증식 효과와 성장인자 발현 촉진 효과를 검증하여 기능 성 화장품 및 육모제 소재로서의 활용 가능성을 살펴보았다.

황칠나무 잎 메탄올-초음파 추출물의 총 폴리페놀 함량 은 $74.082 \pm 7.180 \mathrm{mg} / \mathrm{g}$, 총 플라보노이드 함량은 97.360 $\pm 2.235 \mathrm{mg} / \mathrm{g}$ 로, $\mathrm{DPPH}$ 소거능은 $92.440 \pm 1.023 \%$, 아 질산염 소거능 $52.6 \pm 2.4 \%$ 로 나타났다. P. acnes, $P$. ovale, M. furfur에 대한 항균활성은 세 균주 모두에서 나 타났고, P. acnes에서는 $17.3 \%, P$. ovale에서는 $21.6 \%, M$. furfur에서는 $15.7 \%$ 농도에서 생육이 저해되었으며, 특히 M. furfur와 $P$. acnes에서 항균활성이 우수하게 나타났다.

인간모유두세포에 대한 세포독성은 $10,100,500 \mu \mathrm{g} / \mathrm{mL}$ 의 처리농도 범위 내에서는 유의적인 세포독성은 관찰되지 않았다. 세포생육도는 $\mathrm{PBS}$ 를 처리한 대조군 대비 $10 \mu \mathrm{g} /$ $\mathrm{mL}$ 처리는 $93.5 \pm 3 \%, 100 \mu \mathrm{g} / \mathrm{mL}$ 처리는 $96.1 \pm 5 \%, 500$ $\mu \mathrm{g} / \mathrm{mL}$ 처리는 $102.0 \pm 2.6 \%$ 의 세포생육도를 보였다. 인간 모유두세포에 대한 western blotting을 통한 성장인자 단백
질발현 촉진 및 억제 효과는 대조군 대비 IGF는 $156 \pm 8 \%$ 로 높게 나타나 세포 증식에 기여한다는 것을 확인 할 수 있었으 며, TGF 2 는 $78.3 \pm 10 \%$ 로 억제효과를 보여 탈모 방지 효과를 기대 할 수 있었다.

이러한 결과들을 토대로 황칠나무 잎 메탄올-초음파 추 출물은 항산화능이 높은 것은 물론 인간모유두세포 증식효 과 및 $\mathrm{IGF}$ 발현촉진효과가 있으며, TGF 2 의 억제효과가 있 어 기능성 화장품 및 육모제의 천연소재로 활용가능성이 있 는 것을 확인하였다.

\section{References}

Bae KH, Kim JA, Choi YE. Induction and in vitro proliferation of adventitious roots in Dendropanax morbifera. Journal of Plant Biotechnology, 36: 163-169, 2009.

Bartsch $\mathrm{H}$, Ohshima $\mathrm{H}$, Pignatelli B. Inhibitors of endogenous nitrosation: mechanisms and implications in human cancer prevention. Mutation Research, 202: 307-324, 1988.

Bauer AW, Kirby WM, Sherris JC, Turck M. Antibiotic susceptibility testing by a standardized single disk method. American Journal of Clinical Pathology, 45: 493-496, 1966.

Choi MH, Ryu EM, Oh DS, Shin HJ. Improvement of acne condition in skin care using Camellia japonica L. extracts. Asian Journal of Beauty and Cosmetology, 10: 661-672, 2012.

Choi SK. Growth characteristics of Dendropanax morbifera $\mathrm{L}_{\mathrm{EV}}$ in Wando area of Korea. Korean Journal of Crop Science, 48: 434-437, 2003.

Foitzik K, Spexard T, Nakamura M, Halsner U, Paus R. Towards dissecting the pathogenesis of retinoidinduced hair loss: all-trans retinoic acid induces premature hair follicle regression (catagen) by upregulation of transforming growth factor-beta 2 in the dermal papilla. Journal of Investigative Dermatology, 124: 1119-1126, 2005.

Folin O, Denis W. On phosphotungstic-phosphomolybdic compounds as color reagents. Journal of Biological Chemistry, 12: 239-243, 1912.

Gray JI, Dugan LR Jr. Inhibition of N-nitrosamine formation in model food systems. Journal of Food Science, 40: 981-984, 1975. 
Han EK, Jung EJ, Lee JY, Jin YX, Chung CK. Antioxidative activity of ethanol extracts from different parts of Taraxacum officinale. Journal of the Korean Society of Food Science and Nutrition, 40: 56-62, 2011.

Hibino T, Nishiyama T. Role of TGF-beta2 in the human hair cycle. Journal of Dermatological Science, 35: 9-18, 2004.

Hyung SH, Gang SR, Kim YC. Effect of complex oriental medicine extract on hair growth promotion in an alopecia model of C57BL/6 mice. Journal of the Korean Society of Cosmetology, 13: 1366-1375, 2007.

Jamora C, Lee P, Kocieniewski P, Azhar M, Hosokawa R, Chai Y, Fuchs E. A signaling pathway involving TGFbeta2 and snail in hair follicle morphogenesis. PLOS Biology, 3: e11, 2005.

Kim EH, Han CJ. A comparative study on current use and customer satisfaction according to facility for scalp and hair care. Journal of the Korean Society of Beauty and Art, 15: 59-68, 2014.

Kim EJ, Choi JY, Yu M, Kim MY, Lee S, Lee BH. Total polyphenols, total flavonoid contents, and antioxidant activity of Korean natural and medicinal plants. Korean Journal of Food Science and Technology, 44: 337-342, 2012.

Kim KD, Kim SJ. The study on the efficacy of herbal plant extracts by the part and solvent extraction. Journal of the Society of Cosmetic Scientists of Korea, 33: 127135, 2007.

Kim SM, Cho YS, Sung SK. The antioxidant ability and nitrite scavenging ability of plant extracts. Korean Journal of Food Science and Technology, 33: 626632, 2001.

Kwack MH, Kim MK, Kim JC, Sung YK. Dickkopf 1 promotes regression of hair follicles. Journal of Investigative Dermatology, 132: 1554-1560, 2012.

Kwon MC, Han JG, Ha JH, Oh SH, Jin L, Jeong HS, Choi GP, Hwang B, Lee HY. Immuno-regulatory effect on Centella asiatica L. urban extraction solvent associated with ultrasonification process. Korean Journal of Medicinal Crop Science, 16: 294-300, 2008.

Kwon OS, Han JH, Yoo HG, Chung JH, Cho KH, Eun HC, Kim $\mathrm{KH}$. Human hair growth enhancement in vitro by green tea epigallocatechin-3-gallate (EGCG). Phytomedicine, 14: 551-555, 2007.

Lee HS, Hwang SY. Effects of DCS ${ }^{\circledR}$ hair tonic on hair growth promotion in an alopecia model of $\mathrm{C} 57 \mathrm{BL} / 6$ mice. Asian Journal of Beauty and Cosmetology, 7: 131-141, 2009.

Lee MK, Lee IS, Lee JS. For the utilization of native plant resources as high-value materials: evaluation on demelanizing activity of Dendropanax morbifera in Bogildo. Journal of Korean Island, 25: 227-240, 2013.

Lin WH, Xiang $\sqcup$, Shi HX, Zhang J, Jiang LP, Cai PT, Lin ZL, Lin BB, Huang $Y$, Zhang $\mathrm{HL}$, et al. Fibroblast growth factors stimulate hair growth through $\beta$-catenin and Shh expression in C57BL/6 mice. BioMed Research International, 2015: 730139, 2015.

Mirvish SS. Kinetics of dimethylamine nitrosation in relation to nitrosamine carcinogenesis. Journal of the National Cancer Institute, 44: 633-639, 1970.

Mo JH, Oh SJ. Tyrosinase inhibitory activity and melanin production inhibitory activity of the methanol extract and fractions from Dendropanax morbifera Lev. Asian Journal of Beauty and Cosmetology, 11: 275-280, 2013.

Moon MO, Ihm BS, Chung YC, Kang YJ, Kim CS, Kim MH. Taxonomic appraisal of Dendropanax morbifera Léveillé and D. trifidus (Thunb. ex Murray) Makino based on morphological characters. Korean Journal of Plant Taxonomy, 29: 231-248, 1999.

Mosmann T. Rapid colorimetric assay for cellular growth and survival: application to proliferation and cytotoxicity assays. Journal of Immunological Methods, 65: 55-63, 1983.

Park CS, Kwon CJ, Choi MA, Park GS, Choi KH. Antioxidative and nitrite scavenging activities of mugwort and pine needle extracts. Korean Journal of Food Preservation, 9: 248-252, 2002.

Philpott MP, Sanders DA, Kealey T. Effects of insulin and insulin-like growth factors on cultured human hair follicles: IGF-I at physiologic concentrations is an important regulator of hair follicle growth in vitro. Journal of Investigative Dermatology, 102: 857-861, 1994.

Piddock LJ. Techniques used for the determination of antimicrobial resistance and sensitivity in bacteria. 
Journal of Applied Bacteriology, 68: 307-318, 1990.

Randall VA, Hibberts NA, Thornton MJ, Merrick AE, Hamada K, Kato S, Jenner TJ, de Oliveira I, Messenger AG. Do androgens influence hair growth by altering the paracrine factors secreted by dermal papilla cells? European Journal of Dermatology, 11: 315-320, 2001.

Reuben A, Anaissie E, Nelson PE, Hashem R, Legrand C, Ho DH, Bodey GP. Antifungal susceptibility of 44 clinical isolates of Fusarium species determined by using a broth microdilution method. Antimicrobial Agents and Chemotherapy, 33: 1647-1649, 1989.
Tsuboi R. Growth factors and hair growth. Korean Journal of Investigative Dermatology, 4: 103-108, 1997.

Youm TH, Lim HB. Antimicrobial activities of organic extracts from fruit of Thuja orientalis L. Korean Journal of Medicinal Crop Science, 18: 315-322, 2010. 


\section{국문초록}

\section{황칠나무 잎 추출물의 기능성 화장품 및 육모제 소재 활용 연구}

박윤미, 한진섭*

남부대학교대학원 향장미용학과, 광주, 한국

목적: 본 연구는 황칠나무(Dendropanax morbifera) 잎에서 메탄올-초음파 추출법으로 유효성분을 추출하여 약물요법을 대 체 할 수 있는 기능성 화장품 및 육모제 소재 개발에 자료를 제공하고자 하는 목적으로 수행하였다. 방법: 황칠나무 잎 메탄 올-초음파 추출물의 총 폴리페놀 및 플라보노이드 함량을 측정하였고, 항산화능과 아질산염 소거능을 측정하였으며, 항균활 성과 최소성장저해농도(minimum inhibitory concentration, MIC)를 측정하였다. HFDPC세포에 대하여 10, 100, $500 \mu \mathrm{g} /$ $\mathrm{mL}$ 농도별로 처리하여 MTT assay를 통하여 세포독성을 평가하였으며, western blotting을 통한 성장인자 발현촉진 및 억 제 효과를 측정하였다. 결과: 황칠나무 잎 메탄올-초음파 추출물의 총 폴리페놀 함량은 $74.082 \pm 7.180 \mathrm{mg} / \mathrm{g}$, 총 플라보노 이드 함량은 $97.360 \pm 2.235 \mathrm{mg} / \mathrm{g}$ 로 나타났다. $\mathrm{DPPH}$ 소거능은 $92.440 \pm 1.023 \%$ 로 높은 효과를 보였으며, 아질산염 소거 능은 52.6 $\pm 2.4 \%$ 를 보였다. Propionibacterium acnes (P. acnes), Pityrosporum ovale (P. ovale), Malassezia furfur ( $M$. furfur) 균주에 대하여 항균활성이 나타났으며, 최소성장저해농도(MIC)는 P. acnes에서는 $17.3 \%, P$. ovale는 $21.6 \%, M$. furfur에서는 $15.7 \%$ 농도로 나타났다. 인간모유두세포에 황칠나무 추출물을 $10,100,500 \mu \mathrm{g} / \mathrm{mL}$ 의 처리농도 범위 내에서 세포독성은 관찰되지 않았으며, 농도가 증가할수록 세포생육도가 높았다. Western blotting을 통한 성장인자 단백질의 발현 및 억제 효과는 대조군 대비 IGF는 $156 \pm 8 \%$ 로 발현촉진 효과가, TGF32는 $78.3 \pm 10 \%$ 로 억제효과가 나타났다. 결론: 황칠나 무 잎 메탄올-초음파 추출물은 항산화능을 가진 기능성 화장품 및 육모제의 소재로 활용가능성이 있는 것으로 사료된다.

핵심어: 황칠나무, 인간모유두세포, Western blotting, 성장인자단백질, $\mathrm{DPPH}$

\section{참고문헌}

권민철, 한재건, 하지혜, 오성호, 김영, 정향숙, 최근표, 황백, 이현용. 병풀의 초음파 추출 시 용매에 따른 면역활성 증진 효

과. 한국약용작물학회지, 16: $294-300,2008$.

김경동, 김상진. 약용식물의 부위별 및 추출용매에 따른 효능 연구. 대한화장품학회지, $33: 127-135,2007$.

김수민, 조영석, 성삼경. 식물체 추출물의 항산화성 및 아질산염 소거작용. 한국식품과학회지, 33: 626-632, 2001.

김은진, 최주연, 유미리, 김미영, 이상현, 이복희. 자생식물과 생약자원 추출물의 폴리페놀, 플라보노이드 함량 및 항산화

활성 탐색. 한국식품과학회지, 44: $337-342,2012$.

김은희, 한채정. 두피모발관리 시설에 따른 이용실태 및 만족도 비교연구. 한국인체미용예술학회지, 15: 59-68, 2014.

모정희, 오수정. 황칠나무 잎 메탄올 추출물 및 분획물의 Tyrosinase 저해 및 Melanin 생성억제 활성. 아시안뷰티화장

품학술지, 11: $275-280,2013$.

문명옥, 임병선, 정영철, 강영제, 김찬수, 김문홍. 황칠나무(Dendropanax morbifera Léveillé)와 일본황칠나무 $[D$.

trifidus (Thunberg ex Murray) Makino]의 분류학적 재검토. 식물분류학회지, 29: 231-248, 1999.

박찬성, 권충정, 최미애, 박금순, 최경호. 쑥과 솔잎의 항산화작용 및 아질산염 소거작용. 한국식품저장유통학회지, 9: 248-

$252,2002$.

배기화, 김지아, 최용의. 황칠나무(Dendropanax morbifera)의 부정근 유도 및 기내증식조건. 식물생명공학회지, 36 :

$163-169,2009$.

염태현, 임흥빈. 측백나무 열매 추출물의 항균활성. 한국약용작물학회지, 18: 315-322, 2010.

이미경, 이임순, 이재석. 국내 고유수종의 고부가가치 자원화를 위한 보길도 자생 황칠나무 수액의 미백효능 연구. 
한국도서연구, 25: 227-240, 2013.

이혜숙, 황석연. $\mathrm{C} 57 \mathrm{BL} / 6$ 마우스 모델에서 $\mathrm{DCS}-\mathrm{HT}^{\circledR}$ 발모제의 모발성장 촉진 효과. 아시안뷰티화장품학술지, 7: 131-141, 2009 .

최문희, 류은미, 오득실, 신현재. 동백나무 잎 추출물의 여드름 피부 개선 효과. 아시안뷰티화장품학술지, 10: $661-672,2012$. 최성규. 완도군 황칠나무의 생육특성. 한국작물학회지, 48: 434-437, 2003.

한은경, 정의진, 이지영, 김영섭, 정차권. 민들레의 부위별 에탄올 추출물의 항산화 활성. 한국식품영양과학회지, $40: 56-62$, 2011.

형순희, 강성례, 김영철. C57BL/6 마우스 모델에서 복합 한약추출물의 모발성장 촉진효과. 한국미용학회지, $13: 1366-1375$, 2007.

Tsuboi Ryoji. Growth factors and hair growth. 대한피부연구학회지, 4: 103-108, 1997. 


\section{中文摘要}

\section{黄漆树叶提取物作为功效性化妆品和育发产品原料的应用研究}

朴玧美，韓陳燮”

南部大學校大学院 香裝美容學科, 光州, 韩国

目的: 利用甲醇-超音波提取法提取黄漆树(Dendropanax morbifera)叶的有效成分, 研究其性能, 为代替药物疗法的功效性 化妆品和育发剂原料提供研究资料。方法: 测定黄漆树叶的甲醇-超声波提取物的总多酚含量和类黄酮的含量, 并检测抗氧 化能力、亚硝酸盐的消除能力、抗菌活性和最低抑菌浓度 (minimum inhibitory concentration, MIC) 。对人毛囊真皮乳头 细胞, 用黄漆树叶提取物分别以不同浓度 $10,100,500 \mu \mathrm{g} / \mathrm{mL}$ 进行处理, 并用MTT assay进行测定，应用western blotting 检测生长因子表达的促进效果。结果: 黄漆树叶提取物的多酚含量为 $74.082 \pm 7.180$, 总类黄酮的含量为 $97.360 \pm 2.235$ $\mathrm{mg} / \mathrm{g}$ 。DPPH消除能力为 $92.440 \pm 1.023 \%$ ，显示最高效果，而亚硝酸盐的消除能力为 $52.6 \pm 2.4 \%$ 。黄漆树叶提取物对 Propionibacterium acnes (P. acnes), Pityrosporum ovale (P. ovale), Malassezia furfur (M. furfur) 菌具有抗菌效果, 最低抑 菌浓度(MIC) 依次为 $17.3 \%$ (P. acnes)，21.6\% (P. ovale)，15.7\% (M. furfur)。对人毛囊真皮乳头细胞用黄漆树叶提取物 分别以 $10,100,500 \mu \mathrm{g} / \mathrm{mL}$ 浓度处理时, 没有观察到细胞毒性, 浓度越高, 细胞生长速率越高。通过western blotting观察 生长因子蛋白的表达效果，结果显示与对照群相比IGF的促进效果为156士8\%，TGFß2的抑制效果为 $78.3 \pm 10 \%$ 。结论: 黄漆 树叶的甲醇-超声波提取物具有抗氧化能力, 作为功效性化妆品和育发产品原料充分具有活用可行性。

关键词: 黄漆树, 人毛囊真皮乳头细胞, Western blotting, 生长因子蛋白, DPPH 